\title{
Android based Introduction of Dewata Nawa Sanga Virtual Reality Application
}

\author{
Ni Nyoman Wahyu Rudiasti \\ Students Department of \\ Information Technology \\ Udayana University, Bali, \\ Indonesia
}

\author{
A. A. K. Oka Sudana \\ Lecturer in the Department of \\ Information Technology \\ Udayana University, Bali, \\ Indonesia
}

\author{
Made Sunia Raharja \\ Lecturer in the Department of \\ Information Technology \\ Udayana University, Bali, \\ Indonesia
}

\begin{abstract}
God manifestation in Hinduism which has a duty to look after the universe based on the cardinal points is called Dewata Nawa Sanga. Introduction to Dewata Nawa Sanga has usually started in elementary school or in junior high school. Over the years, the media that is used to learn Dewata Nawa Sanga is from tables and books which are not effective and not interesting. DewataVR application was developed using Virtual Reality (VR) technology as a new learning media in Android platform to overcome the problems. Technology in visualization and simulation field has begun to evolve with VR existence, which simulate a virtual environment. Each God in Dewata Nawa Sanga exists in 9 cardinal point, therefore it requires a Gyroscope Sensor and a Compass Sensor. Gyroscope Sensor is required to detect gravitation movements which rest on a disc that rotate on its axis, whereas Compass Sensor is used as a support sensor in showing cardinal points of each God. DewataVR application make the users as if they were on the cloud and looked at 3D objects of Gods, rides (vehicles), weapons, and information about colors, Aksara, and shrines ruled by each God. Further information about each God is also explained with narrative audio. Applications test was done by quantitative method to find out the respondent satisfactory level after using DewataVR.
\end{abstract}

\section{Keywords}

Hinduism, Dewata Nawa Sanga, DewataVR, Virtual Reality, Gyroscope Sensor, Compass Sensor.

\section{INTRODUCTION}

God manifestation in Hinduism which has a duty to look after the universe based on the cardinal points is called Dewata Nawa Sanga. Dewata Nawa Sanga includes nine Gods, which occupy and guard nine cardinal points. The nine Gods are Dewa Wisnu, Dewa Sambhu, Dewa Iswara, Dewa Maheswara, Dewa Brahma, Dewa Rudra, Dewa Mahadewa, Dewa Sangkara, and Dewa Siwa. Introduction of the Dewata Nawa Sanga is very important to the children, so they know about Dewata Nawa Sanga and its functions.

An advanced technological development allows the existence of application in virtual world. The purpose of virtual technology is to make a delivery of information become more interactive and more effective, because it can give more impact on human senses. Applications of Virtual Reality in education really help the education processes to be more fun and the content can be easily delivered. Over the past years, introduction of Dewata Nawa Sanga is still using tables and books, which are boring and ineffective, which makes students cannot understand and memorize the contents.
Based on the problems associated with learning Dewata Nawa Sanga, an introduction of Dewata Nawa Sanga application was developed using Virtual Reality technology called DewataVR. Virtual Reality technology can be applied in learning media of various fields, such as cultural, history, and tourism. Example application in helping introduction of Dewat Nawa Sanga with Virtual Reality is written in a study, "Game Edukasi Dewata Nawa Sanga" by Made Aditya in 2015. This educational 2D game displays a question, and the answer of that question is matched to parts of the Dewata Nawa Sanga. The parts of Dewata Nawa Sanga that showed in the game are color, Aksara, Urip, Bhuta, Weapons, Rides (vehicles), and Shakti (Goddess) of each God [1].

"Virtual Reality Technology and Museum Exhibit", a study by Michitaka Hirose in 2006, about application of Virtual Technology Reality to visualize various objects that are hard to be understood. This Virtual Reality application use IPT (Immersive Projection Technology). IPT is the most advance VR system. The visualized environment was high in term of quality and very stable because IPT was made by components such as high resolution stereo projector with more than 270 degrees. Virtual environment in this application is very spacious, the players can feel as if they were in the ancient age, walking around the ruins on the other side of the world [2].

"Virtual Reality Surgical Training in Ear, Nose, and Throat Surgery", a study by Department of Otolaryngology, Royal Victorian Eye and Ear Hospital, University of Melbourne in 2014 explained about application of Virtual Reality in medical field, especially in surgery training of ear, nose, and throat. This training simulation using Virtual Reality shows the training environment including the surgery room. This aims to enhance the educational purpose more than the usual method [3].

"Virtual Reality Treatment Versus Exposure in Vivo: A Comparative Evaluation in Acrophobia", a study in 2002 by P.M.G Emmelkamp et al about application of Virtual Reality application in treatment of acrophobia patients. Acrophobia is an excessive fear to high places. The virtual environment that used in this treatment is a real environment like the exposure in vivo program. This study showed that treatment using Virtual Reality is much more effective and the hardware is also much cheaper, so it can reduce treatment with Acrophobia Questioner (AQ) and without doing behavioral study of the acrophobia patients [4].

"Virtual Reality in Brain Damage Rehabilitation: Review", a studying 2005 by F. David Rose, Ph.D et al that explain about application of Virtual Reality technology to help rehabilitation process of brain damage. Despite of high incidence of brain 
damage, brain damage rehabilitation process is still relatively underdeveloped. The focus of this study is to investigate cognitive ability. The results of using Virtual Reality are assessment and rehabilitation of certain disability caused by brain damage, memory dysfunction, spatial disability, and attention deficit to reduce the current symptoms [5].

"A Study of Immersive Game Contents System Design and Modeling for Virtual Reality Technology", a study by Jung Yoon Kim et al in 2014 stated that, this application can simulate physical condition of the users in the real world to the virtual world. The usage of 3D objects make this application become more interesting [6].

"Virtual Reality Use in Architectural Design Studios: A case of studying structure and construction", a study by Wael A. Abdelhameed in 2013 about application of Virtual Reality in architecture field. Method of this study is XML algorithm using micro simulation function, and the evaluation process used qualitative and quantitative method. The main purpose of Virtual Reality in architecture field is to facilitate students understanding the structure of architecture design and construction [7].

"Applying Situated Learning in a Virtual Reality System to Enhance Learning Motivation", a study by Huang Hsiu Mei and Liaw Shu Sheng in 2011 about application of Virtual Reality in learning motivation. Virtual Hospital Situated Learning System (VHSLS) developed a virtual learning environment focused on human anatomy. Application of virtual world that can show $3 \mathrm{D}$ objects to become a more delightful learning place, significantly show that VR is able to enhance learning motivation [8].

"An Evidence-Based Virtual Reality Training Program for Novice Laparoscopic Surgeons", a study by Aggarwal, Rajesh MRCS et al, in 2006 about application of Virtual Reality in medical field. Application of Virtual Reality in learning laparoscopy is used by new laparoscopic surgeons to train their surgery skills before facing a real case. This study includes 40 surgeons who learn in groups. Application of Virtual Reality can enhance students' learning motivation and students' skills to become better laparoscopic surgeons [9].

"Use of Virtual Reality for Adjunctive Treatment of Adult Burn Pain During Physical Therapy: A Controlled Study", a study by Hoffman, Hunter G. Ph.D et al, in 2000 also about application of Virtual Reality in medical field. Application of Virtual Reality also can be a treatment to reduce pain for patients with burn injury. Every patient spends 3 minutes of real physical therapy and another 3 minutes of physical therapy in VR world. The result showed that every patient feel pain while doing physical therapy with VR [10].

"Virtual reality and tactile augmentation in the treatment of spider phobia: a case report", a study by Albert S, Carlin et al, in 1997 about application of Virtual Reality in medical field. Virtual Reality can reduce patients' anxiety, fear, and phobia to spiders. Application of Virtual Reality is proven to be a very effective new treatment modality in helping patients with acute phobia [11].

"Exploring the Use of Computer Games and Virtual Reality in Exposure Therapy for Fear of Driving Following a Motor Vehicle Accident", a study by David G. Walshe et al in 2004 about application of Virtual Reality in medical field. This study shows that Virtual Reality can be used to treat patients with phobia of driving that caused by previous accident (accident phobia). Driving simulation environment in the virtual world is specially designed for patients with phobia, so they can practice. This driving simulation can reduce anxiety felt by patients while driving in virtual world. This study shows that VR is beneficial in treatment of patients with phobia after an accident, even in the most terrifying conditions, such as post-traumatic stress disorder and depression [12].

"3D Terrain Virtual Recreation Application Garuda Wisnu Kencana (GWK) Culture Park", a study by Raditya Martha et al in 2016. This application is made by combining 3D objects into virtual environment which is designed to resemble GWK, this app is equipped with graphic quality setting feature. The navigation key and the first person camera mode found in the app are useful for showing the virtual world of GWK with more reality [13].

According to the previous studies about technology which helps in education, history, and tourism that has been described earlier, up until now there is no study about Dewata Nawa Sanga with Virtual Reality technology using gyroscope sensor and compass sensor. Until these years, introduction of Dewata Nawa Sanga is still using tables and book, which are not effective, and make students unable to understand and memorize the content. Technological development in education really helps in making more delightful ways to deliver learning materials, so that students can understand about Dewata Nawa Sanga. This application makes the users as if they were on the top of the cloud and showing 3D objects of Gods, rides (vehicles), and weapons of each God based on the cardinal points. Another information that shown in this application include Shrine, Aksara, Urip, and Colors of each God.

\section{RELEVANT STUDIES}

\subsection{Virtual Reality (VR)}

Virtual Reality is an unreal environment or an imaginary environment which looks like a real world and make the users forget if they are in virtual world. Coates in 1992 defined Virtual Reality as an electronic environment simulation using eyeglasses and wired-cloth so that the user able to interact in virtual world with real situation [14].

\subsection{Dewata Nawa Sanga}

Dewata Nawa Sanga is one theory in Hinduism about nine Gods or Ida Sang Hyang Widhi Wasa manifestation that guard and rule nine cardinal points. Dewata Nawa Sanga is a manifestation of Sadha Siva greatness that portrayed as a lotus with eight petals (Asta Dala) which represent the almighty Sang Hyang Widhi Wasa. Dewata Nawa Sanga is associated with Sang Hyang Widhi which discussed in Kitab Sweta Swatara Upanisad.The Upanisad itself described Gods which is written in Veda as Brahman, that means Sang Hyang Widhi Wasa or the almighty God. Names of Gods in Dewata Nawa Sanga that occupy and rule nine cardinal points are taken from Sang Hyang Widhi Wasa [15].

\section{METHOD AND DISCUSSION}

\subsection{Design System}

The diagram of how the system facilitates users to use DewataVR application is shown in figure 1 . 


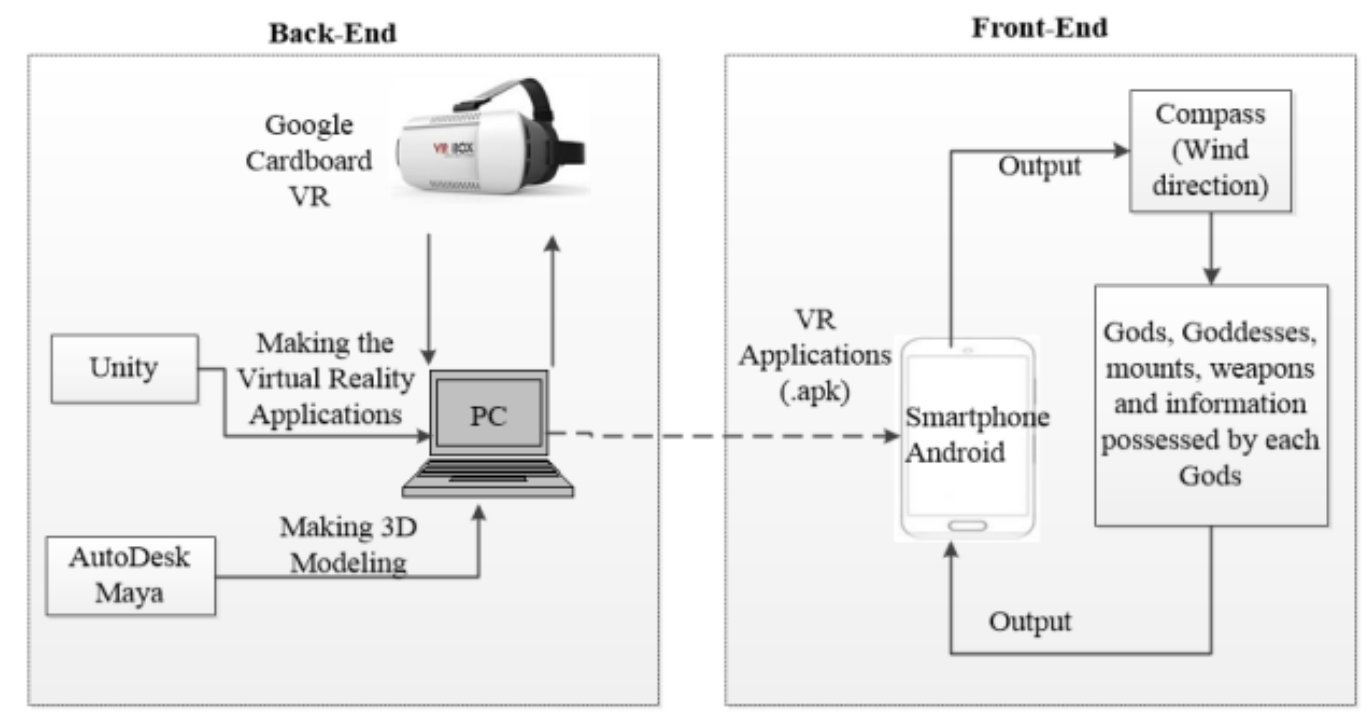

Fig. 1: Design System

Figure 1 is a general view of DewataVR application. The plot in the diagram begin with production of 3D model using Maya Autodesk software, and then designed to become a Virtual Reality application using Unity software which is supported by Google Cardboard. The application is saved in *.apk format and ready to be installed in Android Smartphone. Once the application is installed in Android Smartphone, Google VR will help it run and track the desired location or cardinal point. Object position will be arranged by gyroscope sensor supported by compass sensor. When players are in the game, an Aksara (holy word that represent Dewata) will be shown from distance. The Aksara will float above
Gods palace to show the users the name of each God in each cardinal points, so the players can walk toward the Aksara in order to look closer to 3D objects and gain information regarding each God. The information will be presented as a narrative voice and text on information monument.

\subsection{Use Case Diagram}

Use case diagram is a figure which shows an interconnection between some or all actors, use case, and interaction that introduce a system [16]. Use case diagram of Android Based Dewata Nawa Sanga Virtual Reality Application is showed in Figure 2.

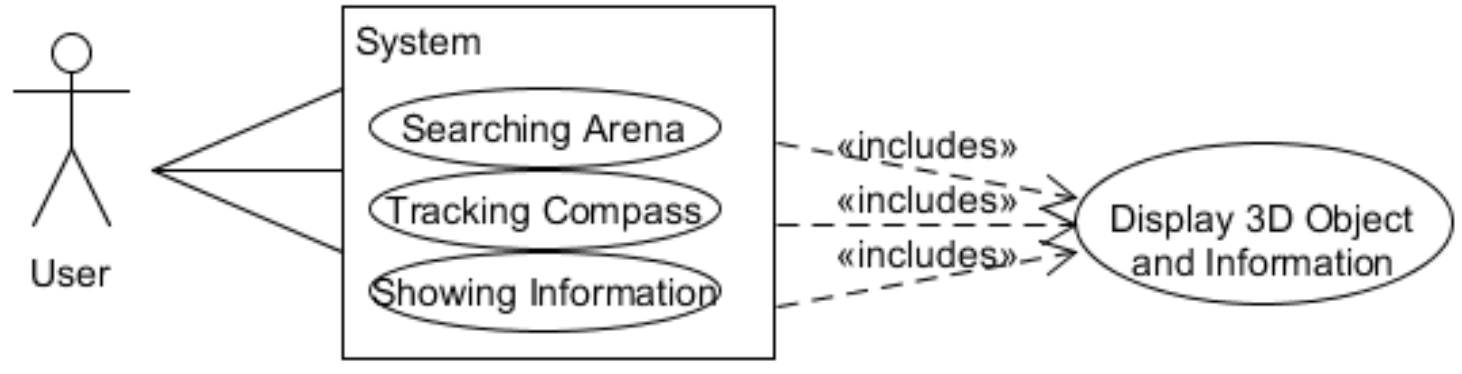

Fig. 2: Use Case Diagram

Figure 2 is a use case diagram of DewataVR application. This application has some features such as searching arena, tracking compass, and showing information. Searching arena feature allow players stroll along the arena which is made by the system. Tracking compass feature determine cardinal points of each God. Information feature shows further information regarding each God which presented as a narrative voice and text in information monument.

\subsection{Activity Diagram}

Activity diagram's role is to describe the development design working plot of the Android Based Dewata Nawa Sanga Virtual Reality application. Activity diagram facilitates users to use the application. Figure 3 is the activity diagram of the DewataVR application.

Figure 3 as an activity diagram of DewataVR application started from the user who walks on the Virtual Reality arena as if they were on a palace above the cloud. Compass sensor helps gyroscope sensor to be more accurate in locating God's position. 3D objects will be shown once the player success finding the desired cardinal point. The players also will be shown an information monument which filled with further information regarding each God that presented as narrative voice and text. 


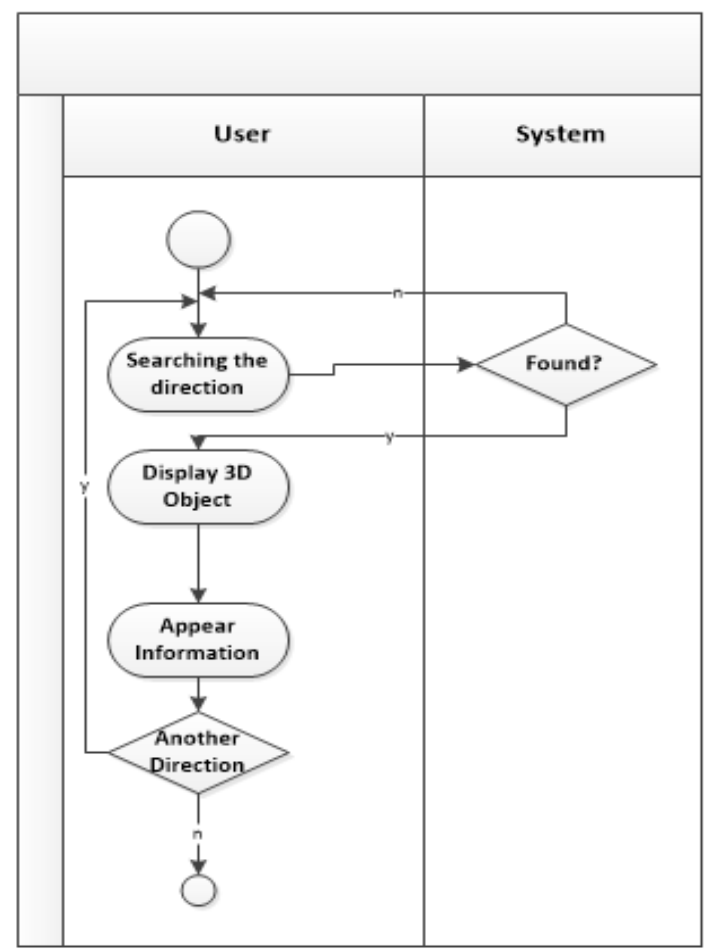

Fig. 3: Activity Diagram

\subsection{D Model}

The 3D model design was implemented using Maya Autodesk software because it will make the $3 \mathrm{D}$ objects looked real and interesting. These are the results of the 3D objects.
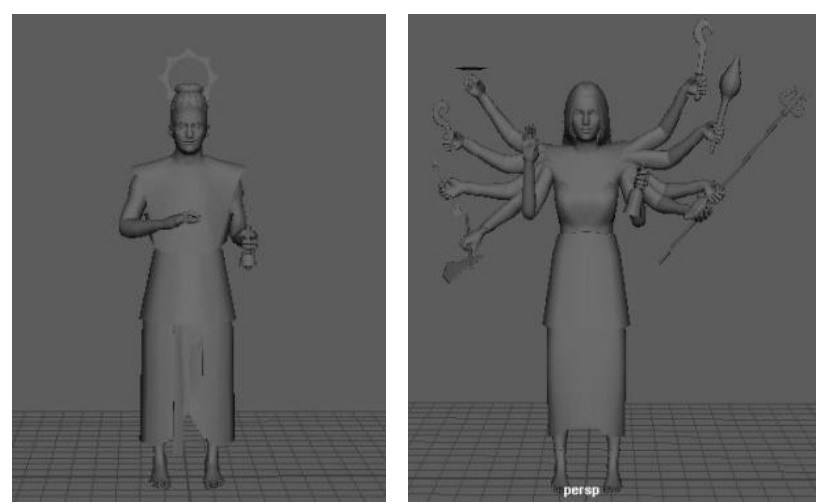

Fig. 4: 3D Objects Design of Gods and Goddesses

Figure 4 shows 3D objects design of Gods and Goddesses. 3D objects was paired with materials to make them look more attractive.
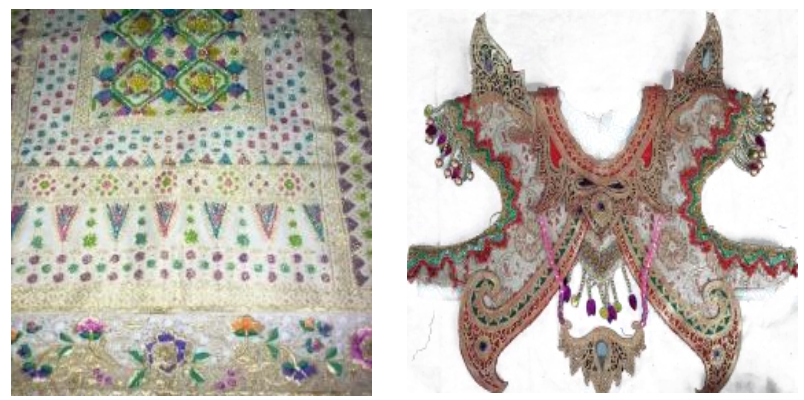
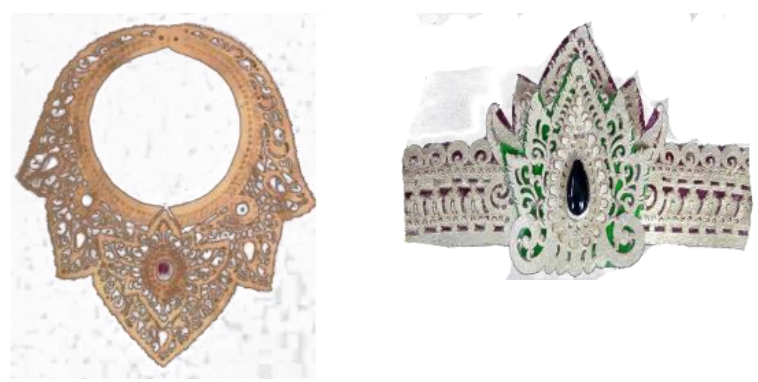

Fig. 5: 3D Objects Material of Gods and Goddesses

Figure 5 shows the material which was used to make 3D objects more interesting, so the final results of 3D objects of God and Goddess looked like Figure 6.
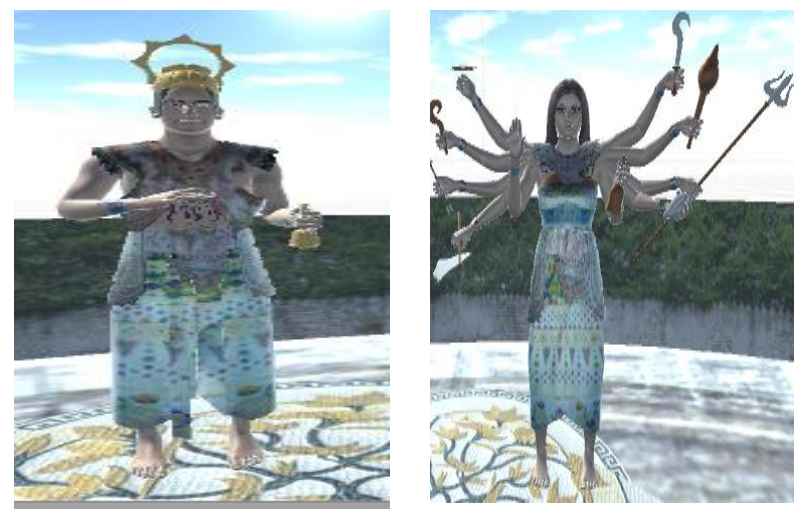

Fig. 6: Final Results of 3D Objects of God And

\section{Goddess}

Figure 6 shows 3D objects of God and Goddess complete with weapons and attributes based on the direction of the cardinal points. 3D models of each God and Goddess are the main objects in Dewata Nawa Sanga Introduction Virtual Reality Application. 


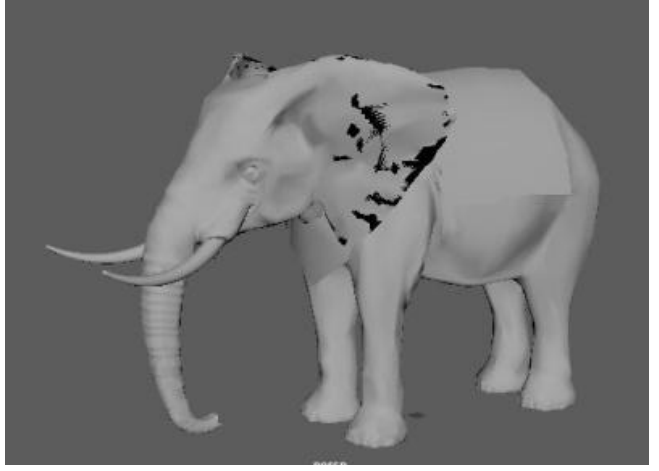

Fig. 7: 3D Rides (Vehicle) Object Design

Figure 7 shows 3D object design of God's Ride (Vehicle). 3D objects was paired with materials to make them looked more attractive.
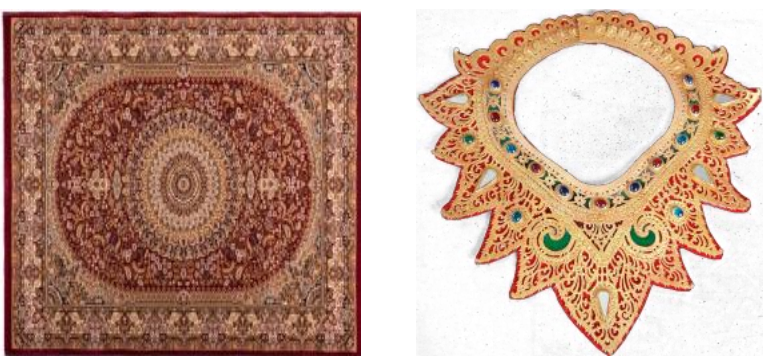

Fig. 8: 3D Objects of Rides (Vehicles)Material

Figure 8 shows the material used to make 3D objects more interesting, so that the final results of 3D objects of the Rides (Vehicle) are like Figure 5.

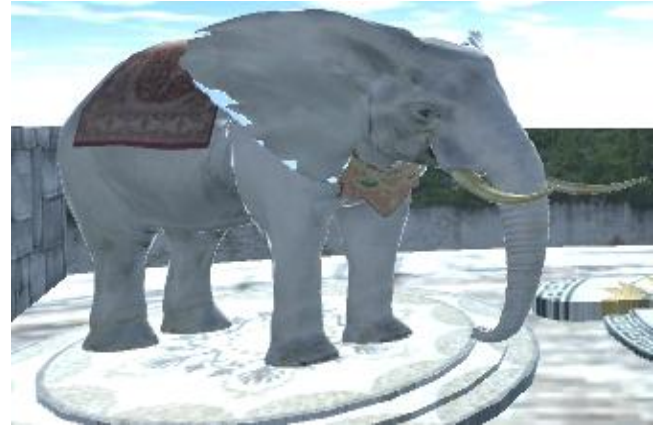

Fig. 9: 3D Objects of Rides (Vehicles)

Figure 9 shows 3D object of the Rides (Vehicle) complete with attributes. The 3D Rides (Vehicle) are supporting objects which are featured in virtual reality application introduction of Dewata Nawa Sanga.

\subsection{Application Test}

DewataVR application test was done with Android device. The aim of this test is to determine how far the application can overcome problems and to evaluate how to develop the application. The device used in testing is the one with android gyroscope sensor and compass sensor.

\subsubsection{Application Test with Device 1}

Device 1 is an android based Smartphone that support sensor and compass sensor. Specifications of the device 1 Smartphone are listed below:

1. Smartphone operating system: Android KitKat

2. Smartphone android processor: Quad-Core 2.3 $\mathrm{GHz}$
3. Smartphone android camera: 13 Megapixel
4. RAM: 3 GB
5. Gyroscope sensor and compass sensor

Results from DewataVR application test using device 1 are listed below.

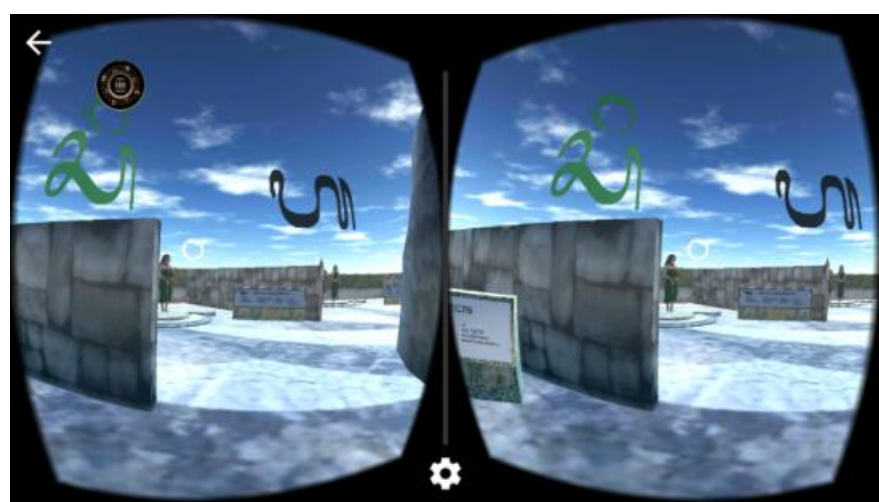

Fig. 10: Result in Device 1

Figure 10 shows the result from DewataVR application test using android device. Once the game is started, a feature of compass sensor, Aksara above the God, God and Goddess objects from distance will be shown.

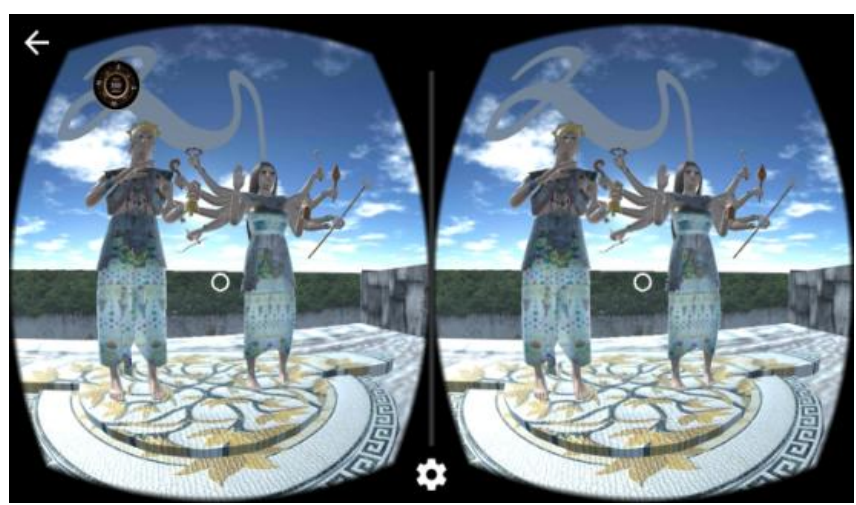

Fig. 11: 3D object testing Device 1

Figure 11 shows 3D object testing in accordance with cardinal points. Gyroscope sensor will determine users' gravitational movement, when users walk toward object and once they are in the desired position, God, Goddess, Aksara, and cardinal points will be shown. There will be information presented by narrative voice regarding each God.

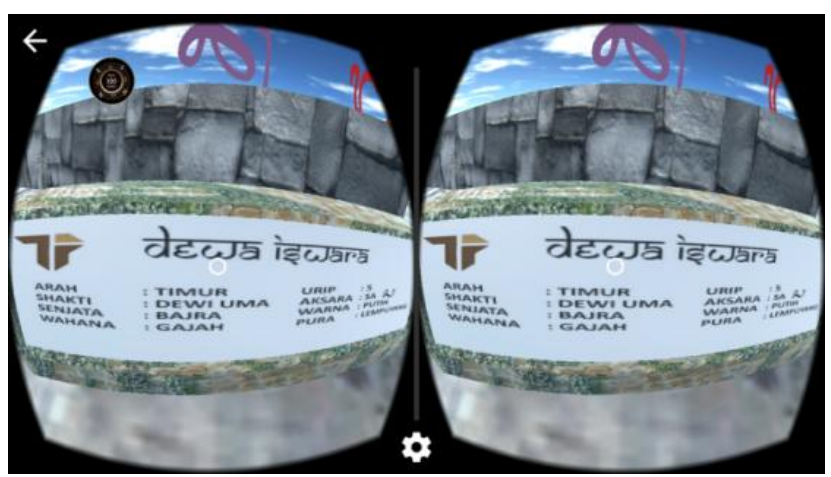

Fig. 12: Information Monument in Device 1

Figure 12 shows information monument of each God based on cardinal points. When users walk toward the information monument, they will see complete information regarding the God, the ruled cardinal point, Shakti (Goddess), Weapons, 
Color, Urip, Aksara, and the shrine based on the cardinal point presented in text format.

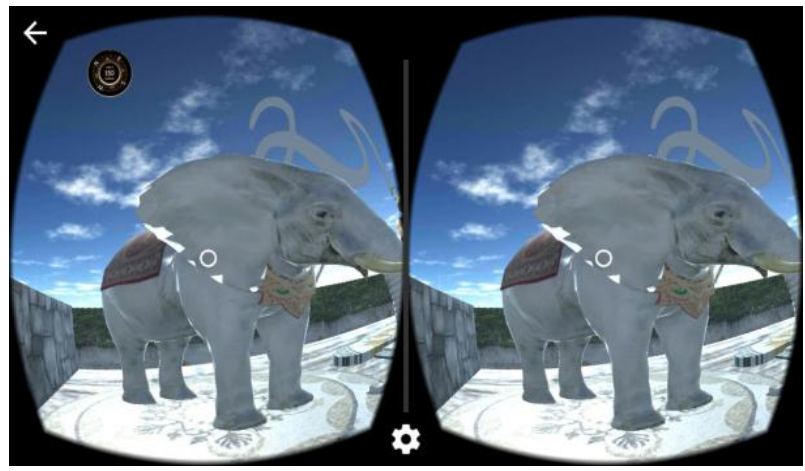

Fig. 13: 3D Object of Ride (Vehicle) Display in Device 1

Figure 13 shows a 3D object of Rides (vehicle) of each God according to the cardinal points.

\subsubsection{Application Test with Device 2}

Device 2 is an android based Smartphone that support gyroscope sensor and compass sensor used in testing DewataVR application. Specifications of the device 1 Smartphone are listed below:

1. Smartphone operating system: Android Lollipop

2. Smartphone android processor: Octa-Core $1.5 \mathrm{GHz}$

3. Smartphone android camera: 13 Megapixel

4. RAM: $3 \mathrm{~GB}$

5. Gyroscope sensor and compass sensor

Results from DewataVR application test using device 2 are listed below.

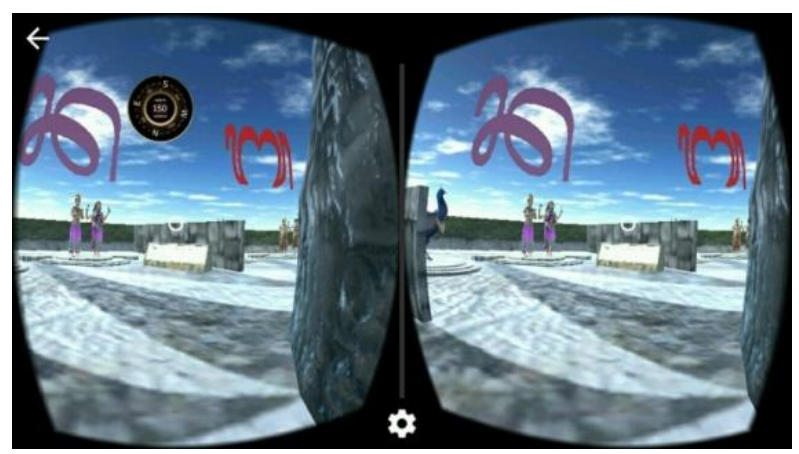

Fig. 14: Result in Device 2

Figure 14 shows the result from DewataVR application test using android device. Once the game starts, a feature of compass sensor, Aksara above the God, God and Goddess objects, and information monument from distance will be shown.

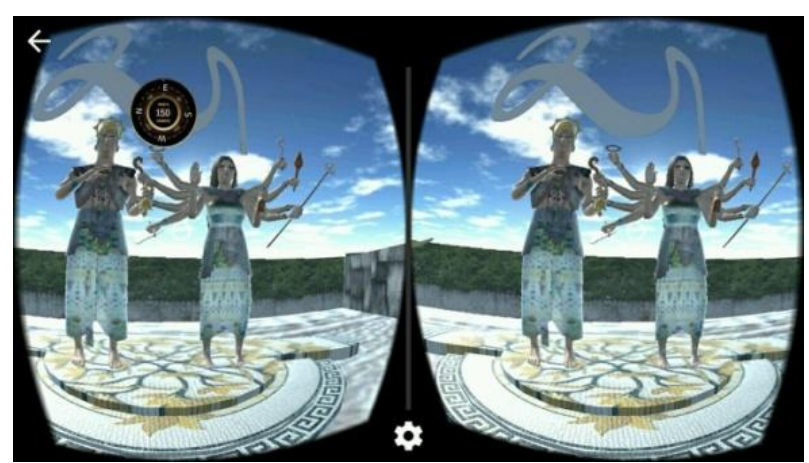

Fig. 15: 3D Object Testing in Device 2
Figure 15 shows 3D object testing in accordance with cardinal points. Gyroscope sensor will determine users gravitational movement, when users walk toward object and once they are in the desired position, God, Goddess, Aksara, and cardinal points will be shown. There will be information presented by narrative voice regarding each God.

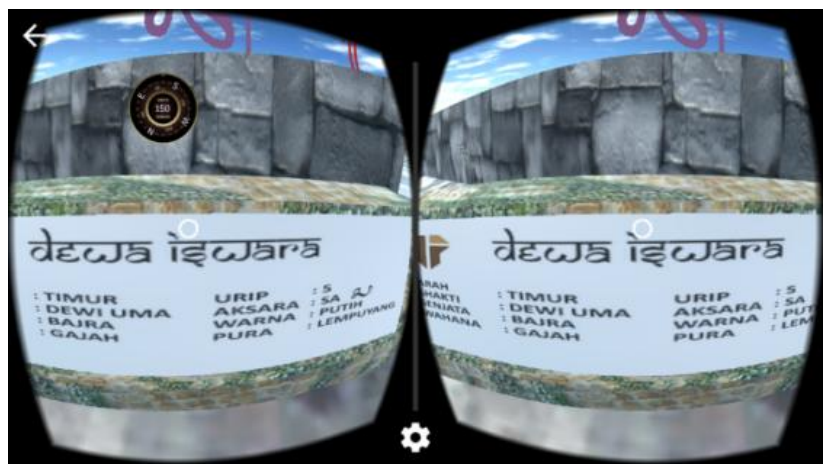

Fig. 16: Information Monument in Device 2

Figure 16 shows information monument of each God based on cardinal points. When users walk toward the information monument, they will see complete information regarding the God, the ruled cardinal point, Shakti (Goddess), Weapons, Color, Urip, Aksara, and the shrine in accordance with the cardinal point presented in text format.

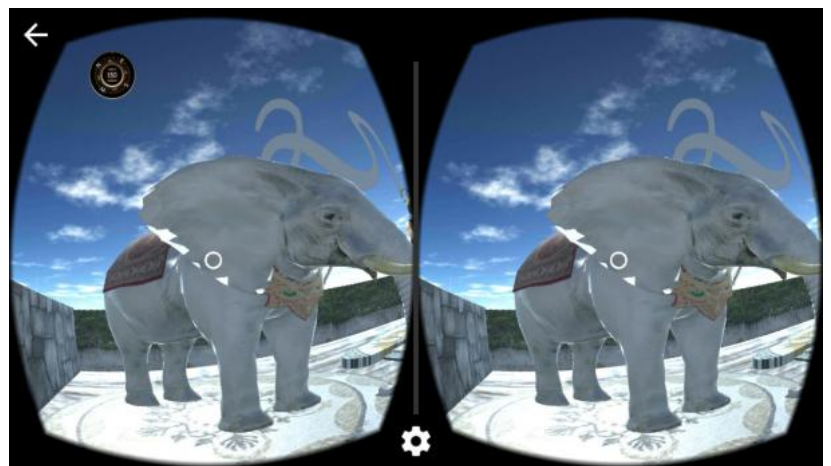

Fig. 17: 3D Object of Ride (Vehicle) in Device 2

Figure 17 shows a 3D object Rides (vehicle) of each god according to the cardinal points.

\subsection{Result of Application Test}

DewataVR application test was done with Android device. The aim of this test is to determine how far the application can overcome problems and to evaluate how to develop the application.

Table 1. Test Result

\begin{tabular}{|c|l|c|c|c|c|}
\hline No & $\begin{array}{l}\text { Device } \\
\text { Name }\end{array}$ & $\begin{array}{l}\text { Dura } \\
\text { tion }\end{array}$ & Display & $\begin{array}{c}\text { Accurat } \\
\text { Compass }\end{array}$ & $\begin{array}{c}\text { Speed } \\
\text { Processing }\end{array}$ \\
\hline 1 & Device 1 & $20 \mathrm{~s}$ & $\begin{array}{l}\text {-Low Resolution } \\
- \text { The position of } \\
\text { compass is on the } \\
\text { left }\end{array}$ & $\begin{array}{c}\text { Accurat } \\
\text { ed }\end{array}$ & $0.25 \mathrm{~s}$ \\
\hline 2 & Device 2 & $25 \mathrm{~s}$ & $\begin{array}{l}\text { - } \\
\text { - The position of } \\
\text { compass is on the } \\
\text { middle }\end{array}$ & $\begin{array}{c}\text { Accurat } \\
\text { ed }\end{array}$ & $0.50 \mathrm{~s}$ \\
\hline
\end{tabular}


Table 1 shows test result from android devices with gyroscope sensor and compass sensor. Results of the test using device 1 which has a higher specification than device 2 are duration of the splash screen process until the game starts is 20 seconds, low resolution with compass on the top left position, and a faster process speed. Whereas results of the test using device 2 , which has a lower specification than device 1 are the duration of the splash screen process until the game starts is 25 seconds, 5 seconds slower than device 1, low resolution with compass on the center position, and slower process speed.

Application testing was done by quantitative method to find out the respondent satisfaction toward DewataVR Application through the assessment questionnaire. The number of respondent are 50 people with 3 aspects of assessment variable. Those 3 aspects of the assessment variables include the conformity aspects of the application process which has function to test whether there is any problem in the application while running on Android devices, user interface aspects which has function to test the display of Nawa Sanga Dewata objects as well as virtual world application display and the last is educational aspects which has function to test the material suitability of Introduction of Dewata Nawa Sanga presented in the application. Results obtained from 50 respondents with 25 questions from 3 aspects of assessment.

Table 2. Questionnaire Results

\begin{tabular}{|l|c|c|c|c|}
\hline $\begin{array}{l}\text { Aspects of } \\
\text { Assessment } \\
\text { Variables }\end{array}$ & SS & A & DA & SDA \\
\hline $\begin{array}{l}\text { Software } \\
\text { Compatibility }\end{array}$ & 169 & 125 & 6 & 0 \\
\hline User Interface & 146 & 104 & 0 & 0 \\
\hline Education & 296 & 154 & 0 & 0 \\
\hline
\end{tabular}

Results obtained from 50 respondents with 20 questions from 3 aspects of the assessment those are on Software Compatibility Aspect which consists of 6 questions, as many as 169 or $56 \%$ of respondents stated strongly agree, 125 or $42 \%$ of respondents agreed, 6 or $2 \%$ stated disagree and 0 or $0 \%$ of respondents stated strongly disagree.

Assessment on User Interface Aspect consists of 5 questions, as many as 146 or $58 \%$ of respondents stated strongly agree, 104 or $42 \%$ of respondents stated agreed, 0 or $0 \%$ of respondents stated disagree and 0 or $0 \%$ of respondents stated strongly disagree.

Assessment on Education Aspect consists of 9 questions, as many as 296 or $66 \%$ of respondents stated strongly agree, 154 or $34 \%$ of respondents stated agree, 0 or $0 \%$ of respondents stated disagree and 0 or $0 \%$ of respondents stated strongly disagree.

The result of percentage score of all tested aspects shows $100 \%$ valid response and $0 \%$ invalid response, so it can be concluded that DewataVR application is an effective tool to help parents and teachers in introducing Dewata Nawa Sanga for children so that they can understand the material better and faster.

\section{CONCLUSION}

Conclusion of this DewataVR application study using gyroscope sensor and compass sensor in helping students' education, especially Hinduism education is DewataVR application can only run in android device supported by gyroscope sensor and compass sensor. The application test was done using quantitative method to find out respondent satisfactory level to DewataVR application with questioner assessment. The amounts of respondents are 50 people with 3 aspects of assessment variables. The 3 aspects of assessment variables are software compatibility aspect to test whether there any problems in the application while run the game in android device, user interface aspect to test Dewata Nawa Sanga objects interface and virtual world view, and educational aspect to test the content of Dewata Nawa Sanga in this application. The results from software compatibility aspect are, $56 \%$ respondents stated strongly agree and $42 \%$ respondents stated agree with the software compatibility while running DewataVR application and it did not have any problems while operating. The results from user interface aspect are, 58\% respondents stated strongly agree and $42 \%$ respondents stated agree with user interface of this DewataVR application. These respondents stated that objects interface on DewataVR application are very interesting to see. The results from educational aspect are, 58\% respondents stated strongly agree and $42 \%$ respondents stated agree with the educational content of the DewataVR application. The respondents stated that DewataVR application can be a delightful learning media, so that it can facilitate the students to understand Dewata Nawa Sanga as a God manifestation who ruled the universe based on the cardinal points. DewataVR application can help to deliver learning materials of Dewata Nawa Sanga in a more delightful visualization by using 3D objects to show Gods, Weapons, Goddess, and Rides (Vehicles) of each God. DewataVR application can be a new effective tool to help parents and teachers to introduce Dewata Nawa Sanga to children or students so that they can understand these subject better and faster. DewataVR applications are expected to be developed for non-Android platforms.

\section{ACKNOWLEDGMENTS}

Thank you Udayana University for the support in this study, especially thanks to the Department of Information Technology, Faculty of Engineering, Udayana University

\section{REFERENCES}

[1] Aditya, Made. 2015. Dewata Nawa Sanga Educational Game.

[2] Hirose, Michitaka, "Virtual Reality Technology and Museum Exhibit", The International Journal of Virtual Reality, 2006.

[3] Departement of Otolaryngology, Royal Victorian Eye and Ear Hospital,"Virtual Reality Surgical Training in Ear, Nose and Throat", International Journal of Clinical Medicine, 2014.

[4] P.M.G Emmelkampa, M Krijna, A.M Hulsboscha, S de Vriesa, M.J Schuemieb, C.A.P.G van der Mast, "Virtual Reality Treatment Versus Exposure in Vivo: A Comparative Evaluation in Acrophobia", Behaviour Research and Therapy, 2002.

[5] F. David Rose, Ph.D. et al, "Virtual Reality in Brain Damage Rehabilitation: Review", CyberPhsychology \& Behavior, 2005. 
[6] Yoon Kim Jung, Nam Sang Hun, "A Study of Immersive Game Contents System Design and Modeling for Virtual Reality Technology", International Journal of Control and Automation, 2014.

[7] Abdelhameed, Wael A, "Virtual Reality Use in Architectural Design Studios: A case of studying structure and construction", Procedia Computer Science, 2013.

[8] Huang Hsiu Mei and Liaw Shu Sheng, "Applying Situated Learning in a Virtual Reality System to Enhance Learning Motivation", International Journal of Information and Education Technology, 2011.

[9] Aggarwal, Rajesh MRCS, Grantcharov, Teodor P. PhD, Eriksen, Jens R. MD, Blirup, Dorthe, Kristiansen, Viggo B. MD, Funch-Jensen, Peter DSc, Darzi, Ara MD, "An Evidence Based Virtual Reality Training Program for Novice Laparoscopic Surgeons", Annals of Surgery, 2006.

[10] Hoffman, Hunter G. Ph.D, Patterson, David R. Ph.D, Carrougher, Gretchen J. R.N. M.N, "Use of Virtual Reality for Adjunctive Treatment of Adult Burn Pain During Physical Therapy: A Controlled Study", The Clinical Journal of Pain, 2000.
[11] Albert S. Carlin, Hunter G. Hoffman, Suzanne Weghorst, "Virtual Reality And Tactile Augmentation In The Treatment Of Spider Phobia: A Case Report", Behaviour Research and Therapy, 1997.

[12] David G. Walshe, Elizabeth J. Lewis, Sun I. Kim, Kathleen O'Sullivan, and Brenda K. Wiederhold. "Exploring the Use of Computer Games and Virtual Reality in Exposure Therapy for Fear of Driving Following a Motor Vehicle Accident", CyberPhsychology \& Behavior, 2004.

[13] Gede Indra Raditya Martha, Putu Agung Bayupati, I Ketut Adi Purnawan, "3D Terrain Virtual Recreation Application Garuda Wisnu Kencara (GWK) Culture Park", Merpati: Vol.4.No.2, 2016.

[14] Anonim. 2016. Key Element Of Virtual Reality.

[15] Dewa Putu Artawan, I Wayan Nuada Endang Sulastri. 2010. Widya Dharma Agama Hindu SMP.

[16] Pratama, Aditya Rahmatullah. 2016. Study UML - Use Case Diagram. 